Psychology of Language and Communication 2011, Vol. 15, No. 2

VERSITAOPEN

DOI: $10.2478 / v 10057-011-0010-4$

\author{
JULIANA STOYANOVA
}

Sofia University St. Kliment Ohridski

\title{
PRECURSORS OF COORDINATE CONSTRUCTIONS: POLISH-BULGARIAN PARALLELS
}

\begin{abstract}
The purpose of this paper is to compare the earliest stages in the ontogeny of coordinate constructions - both phrasal and sentential - in the development of children acquiring two genetically and structurally related languages, Polish and Bulgarian. The data regarding Polish are excerpted from the speech production of 3 of the children belonging to Szuman's corpus included in CHILDES; the Bulgarian data come from 3 Bulgarian subjects whose language development was traced by the author of this paper. The results show that for both languages, the earliest and most primitive forms of coordination consist of sequences containing two or more NPs with existential semantics. The further acquisition of coordinate constructions displays two lines of development. The first line concerns phrasal coordinate constructions including subject, object and adverbial coordinate phrases, whereas the second line affects the development of sentential coordination. The two developmental lines take their course more or less simultaneously, that is, children produce phrasal coordinate constructions on one hand and two types of sentential coordination on the other: such that can be transformed into phrasal coordinate structures by means of the operation of deletion, and such that cannot, so-called irreducible coordinate sentences. Language specificity did not prove to play any important role in the development of coordination in the speech of the Polish and the Bulgarian children. The analyses and discussions emphasize the interplay between children's cognitive, communicative and linguistic development. Key words: early syntactic development, phrasal vs. sentential coordination, subject vs.object phrasal coordination, forward vs. backward deletion, deleted vs. non-deleted coordinate structures, cross-linguistic differences, individual variations
\end{abstract}

\section{Introduction}

This study reopens the discussion about the acquisition of coordination, using naturalistic data from two genetically and structurally related languages - Polish and Bulgarian - as an empirical basis.

The purpose of the paper is to shed light on the earliest stages of the ontogeny of coordinate constructions - both phrasal and sentential - emphasizing the interplay

Address for correspondence: Juliana Stoyanova, Sofia University St. Kliment Ohridski, Faculty of Philosophy, 15 Tsar Osvoboditel Blvd., 1504 Sofia, Bulgaria. E-mail: julianastoyanova@yahoo.com 
between children's cognitive, communicative and linguistic development which displays universal, language-specific and individual characteristics.

\subsection{Theoretical approaches to the acquisition of coordination}

The theoretical approaches towards the acquisition of coordination are influenced by the transformational tradition, so the following issues have been discussed since the 70s and 80s:

- The order of acquisition of sentential versus phrasal forms, and of backward vs. forward deleted forms (Beilin \& Lust, 1975; Lust and Mervis, 1980; De Villiers \& de Villiers, 1985; Lust et al., 2009).

- The way children interpret different forms of coordination - coordination with transitive or intransitive verbs, with subject or object noun phrases, etc. (Ardery, 1980; Clark, 2005, pp. 247-250, etc.).

- The semantics of the coordinate construction connected with or without conjunctions (Bloom et al., 1980; De Villiers \& de Villiers, 1985; PrzetacznikGierowska, 1995).

- Cross-linguistic comparisons and comparisons between experimental and observational findings (De Villiers \& de Villiers, 1985; Tomasello, 2005, p. 266).

- The relation of input to acquisition (Diessel, 2002; Tomasello, 2005, pp. 265-266).

Taking into account that "coordination illustrates the most basic recursive device of natural languages", Lust et al. (2009) suggest that "In the acquisition of coordination, ... the child must assemble knowledge about constituent structure, anaphora, and a wide array of essential linguistic operations."

The notion of forward vs. backward deletion stems from the standard transformational theory, according to which phrasal coordination is a result of an operation of deletion applied to sentential coordinate constructions in the deep structure. Two types of deletion are possible: forward (in the right direction) and backward (in the left direction), as examples $1-4^{1}$ illustrate:

(1) John <loved apples> and Bill loved apples $\rightarrow$ John and Bill loved apples

(2) John loved apples and $<$ John loved $>$ lemons $\rightarrow$ John loved apples and lemons

The backward deletion of the VP in the first clause (example 1) and the forward deletion of the subject and the verb in the second clause (example 2) yields phrasal coordinate constructions - subject and object coordination respectively.

(3) John loved apples and $<$ John $>$ hated lemons $\rightarrow$ John loved apples and hated lemons

(4) John loved apples and Bill < loved $>$ lemons $\rightarrow$ John loved apples and Bill lemons

\footnotetext{
${ }^{1}$ The examples are cited after de Villiers \& de Villiers 1985.
} 
The forward deletions of the second clause subject (example 3) and verb (example 4) result in complex coordinate sentences.

Problematic cases like "John and Sally are a married couple", which cannot be derived on the same structural principle as (1), give rise to alternative interpretations of phrasal coordinates within the theory of government and binding: as ternary branching structures ${ }^{2}$ (cf. Haegeman, 1991, p. 132), or as "gaps" - proforms in the surface structure preceded or followed by their antecedents (Haegeman \& Gueron, 1999, p. 162; De Villiers \& de Villiers, 1985; Lust et al., 2009, pp. 244-245, etc.), as in examples (5) and (6) (cited after Lust et al., 2009, p. 244):

(5) Tweetle beetles battle and [they]/[ㅁ] use paddles.

(6) Tweetle beetles $\underline{\varnothing}$ and Pudgy Wuggies carry paddles.

In contrast to the generative grammar approach which endows children with highly abstract knowledge of the linguistic structure, the functionalist approach views children's skills with complex constructions as "heavily item-based, with a gradual broadening and deepening of competence" (Diessel, 2002; Tomasello, 2005, p. 264).

\subsection{Order of acquisition}

Theoretical expectations based on the logical and linguistic descriptions of coordination give precedence of sentential over phrasal forms, and some empirical data confirm those expectations: "Sentential coordinations ... appear to be developmentally primitive; they are in place when phrasal or reduced coordinations appear" (Lust et al., 2009, p. 246). Analyzing children's imitation, understanding and spontaneous production, Beilin \& Lust (1975), Lust (1977), and Lust \& Mervis (1980) come to the conclusion that sentential forms have primacy over phrasal forms, and forward deletion over backward, the latter suggestion being based on the fact that subject coordination (as in example 1) is infrequent in children's spontaneous production. Tager-Flusberg et al. (1982), however, show that in elicitation conditions children give adequate subject coordination in $75 \%$ of cases (cf. the discussion in de Villiers, de Villiers, 1985, p. 105). Analyses of the spontaneous production of 5 Bulgarian children aged 1;2-2;9 confirm the suggestion regarding earlier developmental stages - precursors of subject coordination appear simultaneously with those of object coordination (Stoyanova, 2009).

According to the alternative structural description, phrasal coordinate constructions are not derived from sentential ones but represent a direct coding of the reference situation in the surface structure of the sentence. Hence, children generate their coordinate constructions in a process of direct combination of con-

\footnotetext{
${ }^{2}$ In the grammatical descriptions of Bulgarian, phrasal coordination is treated in a similar way: coordinate noun phrases like Mary and fohn are generated as a ternary branching NP structure which can be assigned different functions in the clause or sentence: subject, object or adjunct (cf. Penchev, 1998, pp. 558-559).
} 
stituents in the left-right direction (Greenfield \& Dent, 1982; Hakuta, de Villiers \& Tager-Flusberg, 1982). An additional argument in favor of this suggestion is given by Bloom et al. (1980): the authors argue that if phrasal coordination were derived from sentential coordination, wrong deletions like (7) and (8) should be expected much more frequently in children's early spontaneous production ${ }^{3}$.

(7) Mary went home and John.

(8) Likes apples and John lemons.

\section{Precursors of coordination: Polish-Bulgarian parallels}

\subsection{General remarks}

Polish and Bulgarian are not only genetically related (both being Slavic languages), but also share some important structural properties, for example the verbs in these languages are regularly inflected for person and number, which makes the omission of the subject pronouns (and in some contexts the subject NPs) possible. Furthermore, since the agreement between the NP-Subjects and the Verb-Predicates in number is obligatorily marked in the verb inflections, it is possible to conclude from the form of the verbal predicate about the singular-plural quantification of its subject argument. Singular NP-Subjects also agree in gender with their Predicates whenever the latter include participles or predicative NPs taking the gender marking. These (and many other) language- (and language family-) specific features make Polish and Bulgarian interesting objects of investigation regarding the acquisition of morphosyntactic rules.

Previous studies on the acquisition of Polish include such comprehensive descriptions of the emergence of Polish complex sentences as those given by Przetacznikowa $(1976 ; 1978)$ and Smoczynska $(1983 ; 1985)$. It is suggested that, in general, the acquisition of complex sentences by Polish children matches the universal pattern described by Clancy, Jakobsen and Silva (1976), as well as that for English presented in Limber (1973) and Bowerman (1979). At some points, however, it seems precocious (Smoczynska 1985). Complex structures which appear before the age of 2 involve coordination, antithesis, sequence, infinitival embedded clauses and causal adverbial clauses (Smoczynska 1985; Przetacznik-Gierowska 1995). The acquisition of Bulgarian complex sentences is discussed in Stoyanova ${ }^{4}$ (2006; 2009), who also highlights some universal as well as language-specific tendencies.

\subsection{Empirical data}

The empirical data in this study are excerpted from Bulgarian and Polish databases. The 3 Polish children belong to Szuman's corpus included in CHILDES; the

\footnotetext{
${ }^{3}$ According to Greenfield \& Dent (1982), such wrong deletions do occur incidentally, but as late errors.

${ }^{4}$ In his studies dedicated to the morphosyntactic development of his two sons, Georgov (1906) comments the emergence of complex sentences, but his suggestions are incompatible with the contemporary discussion.
} 
Table 1: Description of the Bulgarian and Polish children

\begin{tabular}{lccccc}
\hline Name & Nationality & Age & Sex & $\begin{array}{c}\text { Data collection } \\
\text { method }\end{array}$ & Early speaker \\
\hline Lilia & Bulgarian & $1 ; 4 .-1 ; 11$ & female & diary & + \\
Oni & Bulgarian & $2 ; 2-2 ; 5$ & female & tape recording & - \\
Stefan & Bulgarian & $1 ; 8-2 ; 5$ & male & tape recording & - \\
Basia & Polish & $1 ; 8-2 ; 5$ & female & diary & + \\
Inka & Polish & $1 ; 6-2 ; 2$ & female & diary & + \\
Jaś & Polish & $1 ; 9-2 ; 2$ & male & diary & + \\
\hline
\end{tabular}

Bulgarian data come from 3 Bulgarian subjects whose language development was traced by the author of this paper. Table 1 gives a more detailed description of the subjects involved in this study and their age.

\subsection{Some methodological remarks}

\subsubsection{Data excerption}

As precursors of coordinate constructions, all children's utterances which contain a phrasal or sentential coordination asyndeton, produced either within one turn or divided into two or more turns, are taken into account. Since the lack of conjunctions connecting the clauses in children's sentences makes the difference between coordination and subordination less clear, a kind of formal criterion is applied to distinguish the latter from the former: an utterance is classified as containing coordination if it is syntactically and semantically acceptable after adding a coordinate conjunction, such as the Polish/Bulgarian i/u (and), a/a (and, but), ale/но (but), albo/или (or), etc.

For each child, the initial point of analysis is the age at which s/he starts producing coordinate constructions. This age point varies considerably, so that the time gap between early and late speakers reaches 6-8 months.

The last point of analysis (which also varies individually) is the age at which the children start producing coordinate conjunctions.

Great individual variability is also displayed in the number and type of the coordinate constructions excerpted from the speech production of the Bulgarian and Polish subjects. The picture is further complicated by the difference in the data-collecting methods: diaries for 4 of the children and tape recordings for 2 of them. The latter method of data gathering proves to be less convenient when highly specific and not very frequent linguistic units are to be registered, and this is the case with coordinate phrases and sentences. That is why the examples of coordinate structures excerpted from the speech production of the tape-recorded children is smaller in number and variability. 


\subsubsection{Theoretical expectations}

\subsubsection{Concerning the order of appearance of coordinate structures:}

i. The earliest forms consist of juxtaposed NPs with existential semantics which can be viewed as both phrasal and sentential.

ii. Sentential and phrasal coordinate constructions emerge more or less simultaneously.

iii. The subject phrasal coordinate constructions are not more difficult than the object and adverbial ones although the former are derived by means of backward whereas the latter by means of forward deletion.

iv. Sentential coordinates which are not reducible to phrasal ones develop somewhat later.

v. The coordinate conjunctions are often preceded by subordinate connectors, such as wh-words introducing complement and adverbial clauses.

vi. The conjunction $\mathbf{i} / \mathbf{u}($ and $)$ is not necessarily the first coordinate one to appear.

\subsubsection{Concerning the variability of the data:}

i. Few or no language-specific differences are expected in the development of the Polish and the Bulgarian children.

ii. Individual variations between early and late speakers are predicted.

\subsection{Data analyses}

\subsubsection{Precursors of phrasal coordinations}

The development of phrasal coordination is driven by children's necessity to verbalize "more arguments fulfilling similar semantic roles in one and the same syntactic position" (Penchev 1998: 558).

In this section, the emergence of phrasal coordinates from children's knowledge about the cognitive and structural properties of simple sentences are analyzed and discussed. It is suggested that children are ready to verbalize situations using coordinate subjects without conjunctions (asyndeton) as early as they start using coordinate objects and adverbials (without conjunctions as well).

\subsubsection{Fuxtaposition of NPs with existential semantics}

This stage, however, is preceded by a more primitive one during which children use conjoined NPs that cannot be ascribed any clear constituent function. These earliest phrasal coordinates express the notion of existentiality by enumerating two or more referents in a single speech act (examples 9-12) or in a speech act sequence (example 13): 
(9) $A^{5}: \quad$ Kolko kaki ima tuk?

(How many girls are there here?)

Edna kaka, dve каki...

(One girl, two girls?)

Lilia (1;4,8): Kaka, kaka, čičo, baba, kuče.

(Girl, girl, uncle, Grandma, dog)

(10) A:

Inka (1;5.10): Książka, lala.

Hala ci da lalę i książeczkę ci pokaże.

(Hala is going to give you a doll and to show you a book)

(Book, doll)

(11) Inka (1;6.27) Rybka, rybka, auto.

(Fish, fish, car)

A: Nie ma rybki i auta, Inusia zostawiła

w domu, u tatusia

(There isn't any fish and car, Inka

has left them at home, with Daddy)

(12) Jaś (1;9.9): Kulka, jajko.

(Globe, egg)

(13) Inka (1;7.8): Tu piłka, piłka

(Here ball, ball)

Janko, janko, kurka, janko, janko

(Egg, egg, hen, egg, egg)

królik, królik

(rabbit, rabbit)
Lilia and her mother are looking at a picture book

Inka is expecting to be given a doll and a book

A is giving a bath to Inka who is looking around

Jas is bringing to his mother a little wooden globe and an egg

Looking at a picture book,

turning a page,

turning another page

Functionally, the juxtaposed nouns can be viewed as a "multiplication" of the naming act. Syntactically, they can be interpreted as combinations of single existential clauses (whose existential predicates are omitted). There is, however, an alternative interpretation according to which noun sequences with existential semantics can be viewed as taking a certain syntactic position depending on the way the language verbalizes existentiality. In Bulgarian, the NPs in an existential sentence are usually formal objects, the whole syntactic construction being impersonal, whereas in Polish, they take the syntactic role of subjects. The Bulgarian child's utterance in (9), for example, could be "standardized" as in (14), while the Polish one in (13) is "translated" as in (15): 
(14) Tuk ima kaka, kaka, čičo, baba, kuče

Here has-IMPERS girl-OBJdir, girl-OBJdir, uncle-OBJdir, dog-OBJdir ${ }^{6}$

(There is a girl, a girl, an uncle, Grandma, a dog here)

(15) Tu są janko, janko, kurka, janko, janko

Here are egg-SUBJ, egg-SUBJ, hen-SUBJ, egg-SUBJ, egg-SUBJ

(Here are an egg, an egg, a hen, an egg, an egg)

In their further development, children start using such "ready-made" conjoined NPs, filling subject, (direct) object and adverbial positions with them and thus producing the proper phrasal coordinate constructions.

\subsubsection{Subject coordination and plural predicates: Individual variations}

In the literature, subject coordination is reported to be infrequent in children's spontaneous production and therefore assumed to be more difficult than object coordination (Beilin \& Lust 1975, Lust 1977, Lust \& Mervis 1980). The empirical data about the acquisition of subject coordination in English, however, are rather controversial (cf. the discussion in de Villiers, de Villiers, 1985: 105).

Analyses of the spontaneous production of the Bulgarian and Polish children show that precursors of subject coordination appear very early, simultaneously with those of object coordination, hence the former should not be regarded as more difficult than the latter. The examples of coordinate subjects are not frequent, but this fact should rather be ascribed to pragmatic factors and individual variations.

Individual differences in the earliest stages of children's acquisition of coordinate constructions are considerable and worth mentioning.

Children differ not only in the age they start using coordinate constructions and in their predisposition to produce some types of coordinate constructions over others, but also in the structural properties of the syntactic units they produce.

\subsection{The Bulgarian children's approach}

One of the Bulgarian children, Lilia, started producing phrasal subject coordinations earlier than the other children in the sample (examples 16 and 17).

(16) Lilia (1;4;14): Didi, Mimi [s]edne!

Didie, Mimi sit down-3 ${ }^{\text {rd }}$ PERS-SG!

([Let] Didie [and] Mimi sit down!)
L. is trying to fix the dolls named

Didie and Mimi in a sitting position

In (16), the child connects the verbal predicate "sit down" with two subject arguments - Didie and Mimi. The verb is inflected for $3^{\text {rd }}$ person singular, instead of plural, since the Subject-Predicate agreement in number is still not acquired by the child.

\footnotetext{
${ }^{6}$ Having lost its morphological case system, Bulgarian does not mark direct objects with accusative endings.
} 
Two weeks later, however, some examples of coordinate subjects combined with plural verbs are registered in her speech (cf. 17).
Lilia (1;5): Kaka, bate papat.
Girl, boy eat- $3^{\text {rd }}$ PERS-PL
Describing a picture
(A girl [and] a boy are eating)

The development of this child displays a clear parallel between the acquisition of plural Subject-Verb agreement in the clause on one hand, and the production of subject coordinations on the other. A similar route of development was reported for the other two Bulgarian subjects (Stoyanova, 2009): as soon as they start inflecting verbs with the $3^{\text {rd }}$ person plural endings, examples of subject coordination appear (cf. 18, where the clause is distributed into two turns in the dialogue).

(18) Stefan (2;2): Njama pie k[af]ence az. Samo mama.

Not drink coffee I. Only Mommy.

(I won't drink coffee. Only Mommy [will do this])

A: $\quad$ Samo mama.

Only Mommy.

Stefan: $\quad$ Tate, mama.

Daddy, Mommy

A: $\quad$ Samo tate i mama kakvo pravjat?

Only Daddy and Mommy what do- $3^{\text {rd }}$ PERS-PL

What are only Daddy and Mommy doing?

Stefan: Pijat.

Drink-3 ${ }^{\text {rd }}$ PERS-PL

(They are drinking)

The parallel between the acquisition of plural Subject-Verb agreement in the clause and the subject coordination is not surprising. From the cognitive point of view, the plural NP refers to more than one individual, just like the coordinate NP; the difference between them is due to the fact that the individuals the plural NP denotes belong to the same conceptual class whereas the coordinate subjects refer to individuals from different conceptual classes, i.e. GIRL $S<$ girl ^ girl ^ girl... vs. GIRL ${ }^{\wedge}$ BOY. Children are aware of that parallel as soon as they start naming more than one individual in the same speech act.

\subsection{Inka's strategy: forward instead of backward deletion}

Even if children are aware of the parallel between the plural NP and coordinate NPs early in their cognitive and linguistic development, their production strategies display considerable variations.

Thus, Inka's earliest constructions with subject coordination appear about two months before she starts using $3^{\text {rd }}$ person plural forms of verbs. This fact could 
explain the peculiar coordinate constructions (examples 19-21) the child produces in that period. Resulting from a forward (as in 19a) instead of a backward deletion (as in 19b), these constructions give the child the opportunity to avoid plural verbs she is still not prepared to produce.

(19) $\mathrm{A}$ :

Hanka przyszła, Janusz, Janusz.

(Hanka come- $3^{\text {rd }}-$ PERS-SG, Janusz, Janusz

(Hanka came, Janusz, Janusz)

(20) Inka (1;9.7): Oo konik jedzie, pan, chłopczyk .

Oo, horse goe- $3^{\text {rd }}-P E R S-S G$, man, boy

(A horse is going, a man, a boy)

(21) Inka (1;10.16): Oo, lisek tu jest, gąski.

Oo, fox be- $3^{\text {rd }}$-PERS-SG here, geese

(Oh, here is a fox [and] geese)
Hanka and Janusz are entering the room, coming to Inka

Hanka przyszła i Janusz <przyszedł $>\rightarrow$ Hanka przyszła (i) Janusz

Hanka <przyszła $>$ i Janusz przyszedł $\rightarrow$ Hanka i Janusz przyszli

However, this type of subject coordination does not cease to exist (example 22a.) with the appearance of the plural Subject-Verb agreement (example 22c.) in the speech production of Inka at the age of 1;10-1;11, although single examples (cf. the last clause in 23: sa na polku, Terenia, Martusia) show the child's readiness to overcome her non-standard productions. Moreover, until the age of 2;3 Inka persists in using them, as examples (24) and (25) testify ${ }^{7}$.

(22) a. Inka (1;11.18): Mamusiu, Ewunia tam jest, Adaś

Mommy, Eve be- $3^{\text {rd }}-$ PERS-SG there, Adam

(Mommy, Eve is there, Adam)

b. Moth: Co robi Ewunia i Adaś na polu?

What do- $3^{\text {rd }}$-PERS-SG Eve and Adam in field?

(What is Eve and Adam doing in the field?)

c. Inka: Oni (się) bawią.

They play-3 ${ }^{\text {rd }}$-PERS-PL

(They are playing)

(23) Moth: $\quad$ Nie ma na polu dzieci, poszły do domu.

(There are no children in the field, they went home)

Inka (1;11.17): Nie poszły do domu, $\boldsymbol{s} q$ na polu, Terenia, Martusia

Not go- $3^{\text {rd }}-P E R S-P L$ home, be- $3^{\text {rd }}-P E R S-P L$ in the field, Terenia, Martusia (They didn't go home, Terenia [and] Martusia are in the field)

\footnotetext{
${ }^{7}$ In this period, only one subject coordinate structure with a plural verb was found: Maniek, Kazek ida na spacer (the age of the child is $1 ; 10.4$ ).
} 
(24) Inka (2;2.23): Terenia tam mieszka, Martusia, Haneczka.

Terenia there live- $3^{\text {rd }}$-PERS-SG, Martusia, Haneczka.

(Terenia lives there, Martusia, Haneczka)

(25) Inka (2;3.3): Grażynka idzie, Celinka.

Grażynka come-3 ${ }^{\text {rd }}$-PERS-SG, Celinka.

(Grażynka is coming, Celinka)

A plausible explanation of Inka's inclination to produce, during several months, this type of deviant subject coordinate structures is the support from her environment. Indeed, similar adult-speech examples are registered in Inka's sample. The first one is her mother's utterance in (22b.) whose structure resembles the child's statement in (22a.), i.e. is derived by means of forward instead of backward deletion of the verb. The second one is found in the situation description cited in the CLAN-format from Szuman's CHILDES database in example (26):

(26) @Comment: Age of CHI is 1;8.14

@Situation: Do Inki przyszła Hanusia i Januszek.

To Inka came- $3^{\text {rd }}$-PERS-SG-FEM Hanusia and Januszek.

(Hanusia and Januszek came to Inka)

Such examples given by adults raise the question about the differences between the standard language and the real linguistic input children are exposed to.

\subsection{Jaś's and Basia’s approach: emphasizing similarity}

Jaś's and Basia's tendency to (over-)emphasize the similarity between situations where different subjects perform equal actions or participate in identical events, blocks the backward deletion. The resulting structures are of the type given in 27-29.

(27) Basia (2;0): Misiu płacze, batwanek też płacze?

Teddy Bear weep- $3^{\text {rd }}-P E R S-S G$, snowman also weep- $3^{\text {rd }}-P E R S-S G$

(Teddy Bear is weeping, the snowman is also weeping?)

A: $\quad$ Tak, misiu płacze i bałwanek płacze, bo słoneczko grzeje i misiowi jest słabo. (Yes, Teddy Bear is weeping and the snowman is weeping, because the sun is shining and Teddy Bear feels weak)

(28) Basia (2;0): Misiu ma szalik, batwanek tė̇ ma szalik.

(Teddy Bear has a scarf, the snowman also has a scarf) Basia and her Mother

A:

Tak, misiu ma szalik, bałwanek też ma szalik. are looking at

(Yes, Teddy Bear has a scarf, snowman also has a scarf) a picture book

(29) A: $\quad$ Tak, dziadziu idzie do pracy, a Teresa idzie do szkoły.

(Yes, Grandpa goes to work, but Teresa goes to school) 
Basia (1;10.7): Dziadziu [do] pracy, tata te $\dot{z}$ [do] pracy, tata [do] labati.

Grandpa [to] work-GEN, Daddy also [to] work-GEN, Daddy [to] work-GEN. (Grandpa goes to work, Daddy also goes to work, Daddy goes working)

(30) Anielcia: Idź do tatusia.

(Go to Daddy)

Fath: $\quad$ Czyj to chłopczyk?

(Whose is this boy?)

Fath: $\quad$ Nasz czy cudzy?

(Ours or somebody else's?)

Jaś (1;11.23): Nasz chłopczyk.

(Our boy)

Fath: $\quad$ Prosił go tutaj ktoś?

(Who did invite him here?)

Jaś: $\quad$ Anielcia prosiła, tatuś też prosit.

(Anielcia invited him, Daddy also invited him)

The sentence coordinate constructions in the above examples are irreducible to phrasal ones. Thus, (27a) cannot be simply transformed into (27b) by means of backward deletion, since the scope of the particle $t e \dot{z}($ also $)$ changes, which affects the meaning of the initial sentence; the meaning of (27a) is preserved only in (27c).

(27a) Misiu płacze, batwanek té̇ płacze?

(Teddy Bear is weeping, the snowman is also weeping?)

(27b) ${ }^{*}$ Misiu i batwanek też płacza.

*Teddy Bear and the snowman are also weeping

(27c) Both Teddy Bear and the snowman are weeping

On the other hand, the forward deletion of the VP in (27d), resulting in the elliptic second clause, is a syntactically acceptable model in Polish and Bulgarian; its English translation, however, requires a rather different sentence structure - (27e).

(27d) Misiu płacze, batwanek też.

Teddy Bear is weeping, the snowman also

(27e) Teddy Bear is weeping and so is the snowman

Example (31) produced by Jaś testifies that the child has "discovered" the syntactically well-formed model of (27d) - subject coordination with a forward deletion - although the over-marked equality of the actions performed by the two subjects ( $\boldsymbol{t} e \dot{z}=a l s o$ is used both in the first and the second clause) breaks the syntactic rules of the adult's language.

(31) Jaś (1;10.8): Miku (do) baby poszedt te $\dot{z}$, facilek te $\dot{z}$.

Miku to Grandma went also, Jacilek also

(Miku also went to Grandma, Jacilek also) 
It is worth noting that an utterance given by Jaś's mother displays the same type of deviation from the standard syntax: Lala $\boldsymbol{t} \boldsymbol{e} \dot{z}$ śpiąca i misiu $\boldsymbol{t} \boldsymbol{e} \dot{z}$ śpiący (The Doll is also sleepy and the Teddy Bear is also sleepy), suggesting once more the necessity to reassess the differences between the standard language and the real linguistic input.

Comparing the deviant sentences of the type (19-21), (25) and (26) in Inka's speech with Jaś's example (31), we can conclude that the difference between the two types of constructions is not logical but pragmatic - the latter construction is emphatic, while the former is not. These syntactic-pragmatic variants, typical not only of Polish but of all Slavic languages as well, were not found in the Bulgarian children's sample. How could this fact be explained? Both in Bulgarian and in Polish, similarity can be emphasized not only by means of $\boldsymbol{t e} \dot{z}$ /също (also), but also by means of the particle $\mathbf{i} / \mathbf{u}$ homonymous with the conjunction $\mathbf{i} / \mathbf{u}($ and $)$ and developed from it. In colloquial Polish, however, the latter means of expressing similarity is less frequent than the former, whereas in Bulgarian it is the other way round. The Bulgarian children emphasize similarity either by means of non-deleted coordinate constructions (cf. Lilia at 1;7,7: Padnala čantičkata, kubčetata padnali - The bag fell down, the blocks fell down) or they "postpone" it until the conjunction/particle и (and) appears (cf. Lilia at 1;9.28: Može Lilito da se kačva na dărvo, i koteto može da se kačva - Lili can climb a tree, and/also the cat can climb).

Inka (1;11.1): Inusia ma bilety i lalunia ma też bilety.

\subsubsection{Early coordinated objects and adverbials}

Both the Bulgarian and the Polish children produced sentences with coordinate objects and adverbials, as in (32)-(37). Their early appearance is predicted, on one hand, by children's increasing knowledge about the clause's VP structure (the regimen of the verbs) and, on the other hand, by their awareness that more than one $\mathrm{NP}$ can fill the same syntactic position.

(32) Lilia(1;6;6): [Šte] obue Lilia botinkite, [san]dalkite.

Put on- $3^{\text {rd }}-P E R S-S G$ Lilia the ankle-boots, sandals

(Lilia [will] put on her ankle-boots [and] sandals)

(33) A:

S kogo spiš?

Who do you sleep with?

Ony $(2 ; 2): \quad$ (S) mama, tati.

(With) Mommy, Daddy

(With Mommy [and] Daddy)

(34) Basia (1;8.27): Tu czytaj pani, dziewczynka. Here read-IMPER lady, girl (Read me here about the lady, girl)
Basia asks her mother to read her about the lady and the girls 
(35) Inka (1;9.20): Mamusiu rób Mokę, rób Rima, fufu, auto. Mommy, make Moka, make Rima, train, car Inka brings her Mother (Mommy, make Moka, make Rima, a train, a car) a sheet of paper and a pencil

(36) A:

A gdzie ty chcesz iść?

And where do you want to go?

Basia (1;9.4): Daleko (do) dziadzia, (do) baby (na) spacer

Away (to) Grandpa, (to) Grandma (for) a walk

(37) A:

Gdzie byłeś?

Jaś comes home from a walk

(Where were you?)

Jaś (1;9.18): $\quad$ Spacer ajciu [=babciu] $z$ niania, $z$ Kubusia.

Walk, Granny, with Nanny, with Kubuś.

(For a walk, Granny, with Nanny, with Kubuś)

The Polish children are still not in (full) command of the case system, and both the Polish and the Bulgarian children have still not overcome the telegraph stage with lacking prepositions. Nevertheless, the coordinate phrases in (32)-(37) demonstrate children's ability to expand VPs using phrasal coordination.

Moreover, children start using coordinate phrases expressing not only additive, but also adversative/contrastive relations between the NPs, as examples 38-40 show.

(38) A:

Może pan przyszedł Inusiu?

Mother has heard a man's voice Maybe a man has come, Inka?

Inka (1;8.21): Nie pan, pani.

Not man, lady

(Not a man [but] a lady).

(39) Basia (1;10.29): To pan mamo, nie tata, nie Adam.

This man, Mommy, not Daddy, not Adam

(This [is] a man, Mommy, not Daddy, not Adam)

(40) A:

Szynki ci dać?

Give-INF you ham?

(Shall I give you some ham?)

Jaś (1;10.3): Szynki dać, bułeczki nie!

Give-INF ham, no bread

(Give [me] some ham, not bread)

\subsubsection{Precursors of sentential coordination}

Initially consisting of two juxtaposed clauses without connectors, coordinate sentences express much more complicated semantic relations than coordinate phrases within the clause (cf. Bloom et al. 1980 for English, Przetacznik-Gierowska 1995 for Polish, etc.). The most typical logical relationships between the clauses in 
coordinate sentences - additive ${ }^{8}$ and contrastive/adversative - are registered in the speech of all 6 studied children.

The early speakers started producing additive coordinate sentences resulting from a forward deletion of the subject NP (examples 41-43) before 2;0, and the late speakers - before $2 ; 6$.

(41) Lilia (1;8;11): Едно куче не сушало, паднало!

A dog not obey-3 $3^{\text {rd }}-P E R S-I M P E R F-R E N A R$, fall- $3^{\text {rd }}-P E R S-A O R-R E N A R$ (A dog was disobedient, fell down)

(42) Jaś (1;10.6): Boli nóżka, kłuje

Jaś takes his shoe off

Foot hurt- $3^{\text {rd }}-P E R S-S G$, pierce- $3^{\text {rd }}-P E R S-S G$

([My] foot hurts, prickles)

(43) Inka (1;10.18): (U) babci była .

(At) Grandma be-3 $3^{\text {rd }}-$ PERS-SG-PRET

([She] was at her Grandma's)

Babcia sprzata, maluje.

Grandma clean- $3^{\text {rd }}-$ PERS-SG, paint- $3^{\text {rd }}-$ PERS-SG

(Grandma is cleaning, painting)

In examples (44)-(46), not only the second clause subject is omitted - as the grammatical rule of forward deletion requires - but also the subject of the first clause. This possibility is completely grammatical in Polish and Bulgarian, since both languages allow, besides the deletion of the pronominal subject, the ellipsis of the subject NP as well.

(44) Basia (1;10.19): Adaś pijdzie.

Adaś will come.

Wyśpi (się), pijdzie potem .

Sleep- $3^{\text {rd }}-P E R S-S G$, come- $3^{\text {rd }}$-PERS-SG later.

([He] will sleep late, will come later)

(45) A: $\quad$ Какво да направи тате?

What shall Daddy do?

Oni (на 2;3): Станеш, гункаш!

Stand-2 $2^{\text {nd }}-P E R S-S G$ up, hug-2 $2^{\text {nd }}-P E R S-S G$

([Let you] stand up, give a hug)

(46) Stefan (на 2;3): Сенне хубаво тука, сожи захар.

S. is going to perform

Sit-3 $3^{\text {rd }}-P E R S-S G-P F V$ down nicely here,

put-3 $3^{\text {rd}}-P E R S-S G-P F V$ sugar.

([Let him] sit down nicely here, put sugar)

\footnotetext{
${ }^{8}$ The additive semantics is often inseparable from the causative and temporal one (as in 35 and 37).
} 
The above sentences speak for children's ability to follow the rule of the surface subject(s) "gap". However, children produced non-deleted coordinate structures as well. This problem is faced in the next section.

\subsubsection{Deleted and non-deleted coordinate structures}

Both the Bulgarian and the Polish children give examples of deleted and non-deleted coordinate sentences which appear shortly after they start producing existential coordinate constructions.

As a result of preserving the verbs or predicative NPs in the second clauses, sentential coordinations instead of their structurally synonymous subject (cf. Examples 47-48) or object (as in 49-51) phrasal coordinate units are produced.

(47) Jaś (1;9.13): Ania papa, tatko papa, mama papa. The family is having lunch Ania eat-- $3^{\text {rd }}-P E R S-S G$, Daddy eat- $3^{\text {rd }}$-PERS-SG, Mommy eat- $3^{\text {rd }}$-PERS-SG.

(Ania is eating, Daddy is eating, Mommy is eating)

(48) Jaś (1;9.16): Mama golas, Anka golas.

Mommy naked, Anka naked

(Mommy is naked, Anka is naked).

(49) Basia (1;8.4): Ci patrz tam auto, patrz pani.

Look there car, look lady

(Look at the car there, look at the lady)
In the morning, Mom and Hanna are putting on their clothes.

Showing the cat what is outside

(50) A:

Pokaż oko Inusiu.

Show eye, Inka.

(Show me your eye, Inka).

Inka (1;10.19): Tu mam oko, tu mam nos, tu mam brewki.

Here have-1st-PERS-SG eye, here have-1st-PERS-SG nose, here have-1st-PERS-SG eyebrows

([I] have here my eye, [I] have here my nose, [I] have here my eyebrows)

(51) Inka (2;1.29): Masło kupiłaś, jajka kupitaś pani?

(Butter buy-2-PERS-SG-PAST, eggs buy-2-PERS-SG-PAST, lady?)

([You] bought some butter, [you] bought some eggs, lady?)

The coexistence of deleted and non-deleted structural types of coordinate units shows that children have gained knowledge of the syntactic synonymy between phrasal and sentential constructions and the possibility to derive the former from the latter through the operation of deletion. In the children's samples there are examples showing that they explore their knowledge of the syntactic synonymy, producing both deleted and non-deleted variants of a sentence in adjacent dialog sequences, as in (52a) and (52b), or in one and the same sentence, as in (53a) vs. (53b) and (53c). 
(52a) Basia (1;10.6): (Na) polu ciemno, zimno.

Coordinate phrase

[in] field dark, cold

(It's dark, cold in the field)

(52b) A: $\quad$ Nie, nie chodźcie na balkon bo jest zimno.

(Don't go out to the balcony, because it is cold there)

Basia: $\quad(\mathrm{Na})$ polu ciemno, (na) polu zimno, wiesz? Coordinate sentence

[In] field dark, [in] field cold, know- $2^{\text {nd }}$ PersSg?

(It's dark in the field, it's cold in the field, you know?)

(53) Inka (1;11.13): Ona ma buty, skarpetki, sukienkę ma, głowę tu ma.

(53a)

Ona ma buty, skarpetki,

She have- $3^{\text {rd }}$-PERS-SG shoes, socks

(She has shoes, socks)

sukienkę ma,

dress have- $3^{\text {rd }}$-PERS-SG

(has a dress)

głowę tu ma.

head here have- $3^{\text {rd }}-$ PERS-SG

(has a head)
Coordinate phrase

Coordinate

sentences

In (53), the first clause (53a) contains coordinate object NPs (Ona ma buty, skarpetki - She has shoes [and] socks) to which the NPs in the second (53b) and the third clause (53c) could be added: Ona ma buty, skarpetki, sukienke, gtowe - She has shoes, socks, dress, head. Instead, the child prefers to "include" the latter two object NPs into separate clauses (sukienke ma, gtowe tu ma- [she] has a dress, has a head) - a quasi-rhetoric means aimed at putting emphasis ${ }^{9}$ on them. An alternative explanation could be hypothesized, however: the child produced three clauses instead of one not for stylistic reasons, but simply following her own attention and thought flow.

Juxtaposed clauses (asyndeton) expressing adversative/contrastive relations also appear in "deleted" (cf. also the $1^{\text {st }}$ and $2^{\text {nd }}$ clause in 54: Ania ma duże jabtko, baba mate - Ania has a big apple, Grandma - a little one) and in "non-deleted" forms (examples 55-56).

(54) Jaś (1;10.3): Ania ma duże jabłko, baba małe, Jasiu ma jabłko

Ania have- $3^{\text {rd }}-P E R S-S G$ big apple, Grandma little, Jaś $-3^{\text {rd }}-$ PERS-SG apple (Ania has a big apple, Grandma - a little one, Jaś has an apple)

(55) Inka (1;10.17): Inusia nie płacze, Inusia śmieje (się).

Inusia not cry-3 $3^{\text {rd }}-$ PERS-SG, Inusia laugh- $3^{\text {rd }}-P E R S-S G$

(Inusia isn't crying, Inusia is laughing)

\footnotetext{
9 Children's desire to emphasize similarity as one of the possible reasons for preferring sentential over phrasal coordinates was discussed in section 2.3.4.3.
} 
Table 2. Number and rate of deleted vs. non-deleted coordinate sentences produced by the studied subjects

\begin{tabular}{|c|c|c|c|c|c|c|c|c|c|c|c|c|c|}
\hline \multirow{3}{*}{ Child/Age } & \multicolumn{4}{|c|}{ Deleted } & \multicolumn{4}{|c|}{ Non-deleted } & & & \multirow{3}{*}{$\begin{array}{c}\text { Total } \\
\text { number }\end{array}$} & \multicolumn{2}{|c|}{ Rate } \\
\hline & \multicolumn{2}{|c|}{ Additive } & \multicolumn{2}{|c|}{$\begin{array}{l}\text { Advers- } \\
\text { ative }\end{array}$} & \multicolumn{2}{|c|}{ Additive } & \multicolumn{2}{|c|}{$\begin{array}{l}\text { Advers- } \\
\text { ative }\end{array}$} & \multicolumn{2}{|c|}{$\begin{array}{l}\text { Irreduc- } \\
\text { ible } \\
\text { sentences }\end{array}$} & & Deleted & $\begin{array}{l}\text { Non- } \\
\text { deleted }\end{array}$ \\
\hline & $A^{*}$ & $\mathrm{C}^{*}$ & $\mathrm{~A}$ & $\mathrm{C}$ & A & $\mathrm{C}$ & $\mathrm{A}$ & $\mathrm{C}$ & A & $\mathrm{C}$ & & & \\
\hline $\begin{array}{l}\text { Basia } \\
(1 ; 8-2 ; 2)\end{array}$ & 14 & 0 & 5 & 0 & 9 & 0 & 9 & 0 & 13 & 0 & 51 & $37.2 \%$ & $35.3 \%$ \\
\hline $\begin{array}{l}\text { Inka } \\
(1 ; 6-2 ; 0)\end{array}$ & 45 & 0 & 4 & 2 & 9 & 2 & 5 & 0 & 25 & 1 & 93 & $54.8 \%$ & $17.2 \%$ \\
\hline $\begin{array}{l}\text { Jaś } \\
(1 ; 9-2 ; 1)\end{array}$ & 12 & 4 & 3 & 0 & 9 & 0 & 5 & 0 & 13 & 2 & 48 & $39.6 \%$ & $41.7 \%$ \\
\hline $\begin{array}{l}\text { Lilia } \\
(1 ; 5.20-1 ; 11)\end{array}$ & 3 & 9 & 0 & 0 & 11 & 2 & 1 & 1 & 9 & 16 & 52 & $23.1 \%$ & $28.8 \%$ \\
\hline $\begin{array}{l}\text { Stefan } \\
(2 ; 2-2 ; 5)\end{array}$ & 3 & 1 & 0 & 0 & 1 & 0 & 2 & 0 & 13 & 1 & 21 & $19.0 \%$ & $14.3 \%$ \\
\hline $\begin{array}{l}\text { Oni } \\
(2 ; 2-2 ; 5)\end{array}$ & 3 & 1 & 0 & 0 & 0 & 0 & 0 & & 2 & 8 & 14 & $28.6 \%$ & $0 \%$ \\
\hline
\end{tabular}

$\mathrm{A}^{*}=$ Asyndeton; $\mathrm{C}^{*}=$ Conjunctions

(56) Jaś (1;10.10): Kurka nie ma butki, Jaśko ma butki.

Han have-3rd-PERS-SG no shoes, Jaś have-3rd-PERS-SG shoes

(The hen has no shoes, Jaś has shoes)

In the literature, more attention has been paid to the existence of non-deleted sentential coordinate constructions which could be transformed into phrasal ones than to those examples of sentential coordination which could not.

Table 2 shows the number of phrasal and sentential coordinations in the speech production of the studied subjects, divided into syntactically synonymous deleted and non-deleted constructions on one hand, and irreducible ones on the other. Under irreducible sentences, such sentential coordinate structures are summed up that cannot or need not be transformed into phrasal ones through the operation of deletion. Some syntactic models of them have already been discussed in section 2.4.2. Sentences with additive semantics are summarized separately from those with adversative/contrastive semantics. During the analyzed period of time the children started producing coordinate conjunctions, so the number of sentences with and without conjunctions is given in separate columns in the table.

Table 2 shows a clear quantitative difference between the early speakers (the 3 Polish children and Lilia) and the late speakers (Stefan and Oni). The late speakers 
who started producing coordinate constructions after 2;2 years of age give a much more limited number of them than the early speakers ${ }^{10}$.

The scores of deleted vs. non-deleted coordinate structures create another opposition: Inka (who produced $17.2 \%$ non-deleted vs. $54.8 \%$ deleted constructions) and Oni (whose speech production did not contain any examples of non-deleted coordinates) differ from the other 4 children whose scores show a similar percentage of deleted and non-deleted sentence models.

The speech production of the children varies also regarding the time point at which they start using conjunctions as well as regarding the speed with which the sentences with conjunctions expand, reducing the amount of asyndeton. In this respect, Lilia differs from the other 3 early speakers: since the moment she started using coordinate conjunctions - at the age of 1;9.11 $\boldsymbol{a}$ (but) and at 1;9.21 $\boldsymbol{и}$ (and) - the child abandoned the more primitive way of conjoining the clauses (by mere juxtaposition) in favor of the regular usage of connectors ${ }^{11}$. On the other hand, the early appearance of coordinate conjunctions in Inka's and Jaś's speech production (at the age of 1;9.7 and 1;9.21 respectively) did not change their behavior and remained sporadic for the next 3-4 months.

Basia is the only child among the early speakers who did not produce any coordinate conjunctions during the analyzed period (up to $2 ; 2)^{12}$. Even in the next two months $(2 ; 2$ to $2 ; 4)$ Basia did not give even a single example of the additive coordinate conjunction $\boldsymbol{i}$ (and $)^{13}$. From the moment (at 1;8 years of age) the child started using phrasal and sentential coordination (asyndeton) until the time she began producing coordinate conjunctions (ale at 2;2, albo at 2;4.5, $\boldsymbol{i}$ at 2;4.7, $\boldsymbol{a}$ at 2;7.11), 6 to 9 months had passed. The lack of conjunctions correlates with Basia's longer lasting telegraph speech: she usually omitted prepositions, the reflexive particle sie, many of the prefixes, etc. The only adult-like type of syntactically complex constructions she produced is the one with embedded infinitives, since their structure does not contain connectors.

Stefan gives several examples of coordinate conjunctions starting from 2;3. However, most of them are used not in their proper additive but rather in their

\footnotetext{
${ }^{10}$ It is important, however, to take into account the different methods of data-gathering: diaries for the early speakers and tape recordings for the late speakers. As mentioned in section 2.3.1., diary notes are more suitable than tape recordings for collecting highly specific and less frequent linguistic structures, such as coordinate constructions.

${ }^{11}$ The appearance of coordinate conjunctions was preceded by the usage of subordinate connectors introducing different types of subordinate clauses: relative дето (that) - at the age of 1;7.23, object как ( how) - 1;7.23 да (to) - 1;8.9, temporal като (when) - 1;8.9, дали (whether) - 1;9.4, къде (where) - 1;9.21, final (за) да (for...to) - 1;8.28 and causative защото (because) - 1;9.8. During the period studied (until the age of 1;11), the child started producing several new conjunctions (the relative $\boldsymbol{\varphi} \boldsymbol{e}-\boldsymbol{t h a t}$, the conditional ако - if, etc.) and used all of them regularly.

${ }^{12}$ The only conjunction registered in Basia's production was the causative subordinate bo (because) in repetition.

${ }^{13}$ However, she incidentally produced utterances containing the adversative $\boldsymbol{a l e}(\boldsymbol{b u} \boldsymbol{t})$ - at 2;2, 2;3 and 2;3.29 Incidental production of subordinate connectors introducing object clauses is also registered: dlaczego (why) at 2;2.13 and jakie (what) at 2;3.24.
} 
discourse pragmatic function. The same is true for the other late speaker, Oni, who (about the age of 2;5) produces more coordinate units with conjunctions than asyndeton (cf. Table 2): $\mathbf{и}$ (and) is usually placed at the beginning of the sentences and serves the pragmatic function of emphasizing similarity.

\section{General discussion and conclusions}

The analyses of the excerpts confirm the order of acquisition predicted in 2.3.2.1.

The earliest and most primitive forms of coordination consist of sequences containing two or more NPs with existential semantics. Functionally, they can be viewed as a "multiplication" of the naming act. These noun sequences, representing a kind of transition between one- and multi-word combinations, are neutral regarding the phrasal-sentential contrast. In their further development, children start using such "ready-made" conjoined NPs, filling the subject, object and adverbial positions with them and thus producing the proper phrasal coordinate constructions.

Further acquisition of coordinate constructions displays two lines of development.

The first line concerns phrasal coordinate constructions including subject, (direct) object and adverbial coordinate phrases.

Analyses of the Bulgarian and Polish data speak in favor of the hypothesis that phrasal coordination initially develops as a result of children's grammatical knowledge about the clause constituent structure. Precursors of subject coordination appear very early, simultaneously with those of object coordination; hence, the former should not be regarded as more difficult than the latter (contrary to the suggestions given in Beilin \& Lust 1975, Lust 1977, Lust \& Mervis 1980, Lust et al. 2009: 246, etc.).

The second line affects the development of sentence coordination. Coordinate sentences stem from children's discourse knowledge - the knowledge that, in subsequent moves or turns of the dialogue, clauses are produced that make sense together.

The two developmental lines take their course more or less simultaneously, that is, children produce phrasal coordinate constructions on one hand, and two types of sentential coordinations on the other: such that can be transformed into phrasal coordinate structures by means of the operation of deletion, and such that cannot, so-called irreducible coordinate sentences. Thus children are able to discover the syntactic synonymy between phrasal and sentential constructions and the possibility to derive the former from the latter. Exploring their knowledge of syntactic synonymy, children sporadically produce both deleted and non-deleted variants of a sentence in subsequent clauses or adjacent dialog turns.

The fact that children use non-deleted sentence coordinations in contexts where phrasal ones are expected has often been interpreted as a kind of syntactic error, thus leaving the impression that as far as children gain the necessary syntactic knowledge, they should start using (mostly/only) deleted structures (cf. the discussion in de Villiers \& de Villiers 1985). Viewed as purely formal structures, these 
sentences seem to be "half-way" to the standard syntactic models; put in their real contexts, however, they seem pragmatically adequate: as emphatic constructions, they underline the similarity between the events coded in the two clauses ${ }^{14}$.

Children also produce certain sentential coordinate models which are not reducible to phrasal ones. These constructions are a sign of an important developmental achievement showing how children develop their syntactic knowledge from discourse-dependent (quasi)-emphatic juxtaposition of clauses to contextindependent coordinate sentences.

It was predicted that coordinate conjunctions are often preceded by subordinate connectors, such as wh-words introducing complement clauses. This prediction proved true for only one of the children - Lilia - who started using subordinate conjunctions about 2 months (at 1;7,23) before coordinate ones (at 1;9.21).

In most cases, $\mathbf{i} / \mathbf{u}$ (and) was the first coordinate conjunction to appear. However, two exceptions were registered: in the speech production of Lilia, a (with contrasting semantics: but/and) was used about 10 days before $\mathbf{и}($ and), and in Basia's sample, the appearance of $\boldsymbol{i}$ (at $2 ; 4.7)$ was preceded by single examples of ale (at 2;2) and albo (at 2;4.5).

This kind of variability is not explicable by means of cross-linguistic or individual (in the sense of rate or style of acquisition) differences. Rather, the use of the conjunctions as formal signs of logical-semantic relationships in children's speech reveals children's drive to be more informative: the less specific $\mathbf{и}($ and $)$ is neglected in favor of the more concrete $\boldsymbol{a}$ (contrastive/adversative), ale (but) and albo (or).

The data analyses confirmed the predictions that in the acquisition of coordination, language specificity did not play any important role in the development of the Polish and the Bulgarian children. The only more or less clear cross-linguistic difference is registered in the acquisition of subject coordination; as soon as the Bulgarian children start inflecting verbs with $3^{\text {rd }}$ person plural endings, examples of subject coordination appear, whereas there is no such correlation for the Polish children. This difference found in a naturalistic study with few cases per language requires further investigation.

The predicted individual variations between early and late speakers did not prove realistic. Indeed, some interesting individual strategies of acquisition of coordinate constructions were registered and discussed: the deviant examples of subject coordination produced by means of forward instead of backward deletion (cf. section 2.4.1.2.2.) in Inka's sample, or the lack of non-deleted coordinate sentences in the speech production of Oni (section 2.4.3). However, these differences between the studied subjects did not differentiate the group of late speakers (Stefan and Oni) from the group of early speakers (the other 4 children), as was supposed.

In his recent monograph study on the acquisition of complex sentences in English, Diessel (2002) concludes that "conjoined clauses evolve by integrating two

\footnotetext{
${ }^{14}$ It is a universal tendency for emphasis to be expressed by means of repetition or, in the case of coordinate
} constructions, by means of a lack of deletion. 
separate sentences into a specific bi-clausal construction. The earliest conjoined clauses are independent sentences that are pragmatically linked to an utterance in the previous discourse. Although these structures may include a connective, they comprise two clauses that are grammatically independent." The investigation of the precursors of coordination in this paper show the opposite process: children are able to integrate coordinate constructions, not only phrases within the clause (in Polish - initially marked by means of case inflexions and then, after overcoming the telegraph stage, with prepositions, and in Bulgarian - only by means of prepositions), but also clauses within the sentences. In the period of lacking conjunctions (asyndeton), integration is formally expressed by means of a subject deletion in the second clause, as the grammatical rules of the adult languages require. Such sentences are not incidental (cf. the columns of irreducible sentences in Table 2 and the analyses of examples 41-46) and their number increases significantly by the time children start producing coordinate conjunctions. Hence, if the earliest conjoined clauses seem to be "independent sentences that are pragmatically linked to an utterance in the previous discourse," this may be due to the fact that the conjunction and in its function of emphasizing similarity between situations develops a particle-like meaning which in all Slavic languages has led to the homonymy between $\mathbf{i} / \mathbf{u}$ (and) as conjunctions and as discourse particles.

Analyses of the precursors of coordination in Bulgarian and Polish have shown that children develop their knowledge of coordinate structures in a several-monthlong process starting from the earliest multi-word combinations with existential semantics, through learning the phrasal/ sentential synonymy between certain types of coordinate constructions, and proceeding simultaneously to the acquisition of coordinate sentences which are irreducible to phrasal ones, until the explicit marking of coordinate relationships by means of conjunctions replaces the more primitive asyndeton.

\section{References}

Ardery, G. (1980). On coordination in child language. Fournal of Child Language, 7, 305-320.

Beilin, H. \& Lust, B. (1975). Connectives: Logical, Linguistic, and Psychological Theory. In H. Beilin (Ed.), Studies in the cognitive basis of language development (pp. 186-217). New York: Academic Press.

Bloom, L.M., Lahey, M., Hood, L., Litter, K., \& Fiess, K. (1980). Complex sentences: Acquisition of syntactic connectives and the semantic relations they encode. Journal of Child Language, 7, 235-261.

Bowerman, M. (1979). The acquisition of complex sentences. In P. Fletcher \& M. Garman (Eds.), Language acquisition (pp. 285-306). Cambridge: Cambridge University Press. 
Clark, E.V. (2005). First language acquisition. Cambridge University Press.

Clancy, P., Jakobsen, T. \& Silva, M. (1976). The acquisition of conjunction: A crosslinguistic study. Papers and Reports on Child Language Development, 12, 71-80.

De Villiers, J.G. \& de Villiers, P. (1985). The Acquisition of English. In D.I. Slobin (Ed.), The crosslinguistic study of language acquisition. Volume 1: The Data (pp. 27-139). Hillsdale, NJ: Lawrence Erlbaum.

Diessel, H. (2002). The development of complex sentence construction in English: A usage-based approach. Hochschulschrift aus CD-ROM. University of Leipzig.

Georgov, I. (1906): Prinos kăm gramatičnija razvoj na detskija govor. Godišnik na Sofijskija universitet, 2, 3-141 (II. Naučen del).

Greenfield, P.M. \& Dent, C.H. (1982). Pragmatic factors in children's phrasal coordination. fournal of Child Language, 9, 425-444.

Haegeman, L. (1991). Introduction to government and binding theory. Oxford: Blackwell.

Haegeman, L. \& Guéron, J. (1999). English grammar: A generative perspective. Oxford: Blackwell.

Hakuta, K., de Villiers, J.G. \& Tager-Flusberg, H. (1982). Sentence coordination in Japanese and English. Journal of Child Language, 9, 193-207.

Limber, J. (1973). The genesis of complex sentences. In T. Moore (Ed.), Cognitive development and the acquisition of language (pp. 169-185). New York: Academic Press.

Lust, B. (1977). Conjunction reduction in child language. fournal of Child Language, 4, 257-288.

Lust, B., Foley, C. \& Dye, C.D. (2009). The first language acquisition of complex sentences. In E.L. Bavin (Ed.), The Cambridge handbook of child language (pp. 237-257). Cambridge: Cambridge University Press.

Lust, B. \& Mervis, C. (1980). Development of coordination in the natural speech of young children. Journal of Child Language, 7, 279- 304.

Penčev, J. (1998). Sintaksis. In T. Bojadžiev, I. Kutsariv \& J. Penčev (Eds.), Săvremenen bălgarski ezik. Finetika, leksikologija, slovoobrazuvane, sintaksis (pp. 498-655). Sofia: Petă Beron.

Przetacznikowa, M. (1976). Additive and contrastive relations expressed in preschool children's speech. Polish Psychological Bulletin, 7, 45-54.

Przetacznikowa, M. (1978). Functions of inclusive coordinate constructions in early development. Polish Psychological Bulletin, 9, 231-238.

Przetacznik-Gierowska, M. (1995). Functions of resultative coordinate constructions in early language and logical development from children's acquisition of Polish. In K.E. Nelson \& Z. Reger (Eds), Children's language. Vol. 8 (pp. 203-223). Hillsdale, NJ: Lawrence Erlbaum.

Smoczyńska, M. (1983). Analiza strukturalna i funkcjonalna sekwencji wypowiedzeń w mowie dzieci w wieku 1;6-2;0. In I. Kurcz (Ed.), Studia z psycholingwistyki ogólnej i rozwojowej (pp. 201-214). Warszawa: Ossolineum. 
Smoczyńska, M. (1985). The acquisition of Polish. In D.I. Slobin (Ed.), The crosslinguistic study of language acquisition. Volume 1: The Data (pp. 595-686). Hillsdale, NJ: Lawrence Erlbaum.

Stoyanova, J. (2006). Psiholingvistični izsledvanija. Sofia: Veda Slovena - ŽG.

Stoyanova, J. (2009). Frazova i izrečenska koordinacija v ontogenezata. Bălgarska reč, 1/2, 21-33.

Stoyanova, J. (2010). Nov pogled kăm "telegrafnata" reč v rannata ontogeneza: Prozodični ograničenija. Contrastive Linguistics, 35 (1), 43-59.

Tager-Flusberg, H., de Villiers, J.S. \& Hakuta K. (1982). The development of sentence coordination. In S.A. Kuczaj (Ed.), Language development. Vol. 1: Syntax and semantics (pp. 201-243). Hillsdale, NJ: Lawrence Erlbaum.

Tomasello, M. (2005). Constructing a language: A usage-based theory of language acquisition. Cambridge, MA: Harvard University Press. 